\title{
EFFECTS OF COOKING AND GERMINATION ON PHYSIOCHEMICAL PROPERTIES AND SENSORY ATTRIBUTES OF AFRICAN WALNUT (TETRACARPIDIUM CONOPHORUM)
}

\author{
A. Ihemeje, O. Ukauwa, C.C. Ekwe \\ Department of Food Science and Technology \\ Imo State University, Owerri, NIGERIA. \\ Corresponding author: austinihemeje@yahoo.com
}

\begin{abstract}
Effect of cooking and germination on physiochemical and sensory attributes of African walnut were investigated. Result proved that the protein $(14.90 \%)$ carbohydrates $(15.39 \%)$ fat $(45.84 \%)$ ash $(3.5 \%)$ and fibre $(1.17 \%)$ contents of the raw samples were increased by germination but subsequently decreased as germination progresses. Cooking was found to be more effective in reduction of antinutrients than germination thereby leading to enhanced bioavailability of most essential minerals (calcium, magnesium, sodium, phosphorus etc). Results also indicate significant $(\mathrm{P}<0.05)$ improvement on the functional properties (water absorption capacity, oil absorption capacity) of the raw sample by cooking and germination. Evaluation of sensory attributes showed that cooked walnut was most preferred to germinated and boiled walnut in terms of taste, after taste and general acceptability.
\end{abstract}

\section{INTRODUCTION}

Germination according to Bahari, (2012) is a biochemical process that involves breakdown and utilization of macromolecules leading to an upshot of cleoptiles. It is a viable process of generation and regeneration (propagation of all kinds of seeds and nuts including African walnut). Nuts, botanically are indehiscent, one seeded fruit derived from two or more carpels having a hard dry pericarp \{shell\} when mature and some hard and dry accessory tissues \{hull\} derived from basal appendages of the flower \{sepal, petal\} or from the involucres \{bracts, bracteoles\}. Common examples of true nuts according to this definition are the walnuts, pecan, chestnuts, etc. \{Encyclopedia Americana, 1995\}. "Nuts are inexpensive and easy to obtain. Due to their low moisture contents, they are concentrated foods which can withstand transportation, rough handling and low temperature. If kept cool, they rarely spoil; otherwise they may deteriorate by becoming rancid or must" $\{$ Hill, 1937\}.

Walnut \{Tetracarpidium conophorum\}, a tropical rambling perennial woody plant of the family Euphorbiacea, is widely distributed and consumed by the inhabitants of the Guinean zone of West and Central Africa \{Oyenuga, 1975\}. It has a weak stem with long internodes and serves well when intercropped with cocoa. Also interplanting walnut plantations with a nitrogen fixing plan such as Elaeagnus ebbingei Elaeagnus umbellate, and various alnus species results in a $30 \%$ increase in true height and girth \{Hemery, 2001\}.

\section{EFFECTS OF GERMINATION ON BIOCHEMICAL COMPOSITION OF NUTS AND SEEDS}

According to Uwaegbute et al. (2012), the quality of foods lefts may be improved by processing. This may involve boiling, autoclaving and sprouting/ germination. Germination is a natural process of all superior plants by which the seen comes out of its latency stage (Sangnis and Machado, 2007). The process of germination has been developed in some countries as an alternative to defeat some of the disorders associated tastes and smell as well as the presence of antinutritional factors (Sangonis and Machado, 2007). Studies have shown that germination improves the nutritive value of cereals and legumes (Onwuka et al., 2009; Mohammed et al., 2011). 


\section{MATERIALS AND METHODS}

\section{Sample Collection and Preparation}

African walnuts were picked under a walnut plant at Awo-Omamma in Oru East Local Government Area. The walnuts were divided into 4 batches. The first batch was not germinated (cooked). The second batch was germinated for one (1) day. The fourth batch was germinated for four (4) days whole the third batch was germinated for eight (8) days. Water was being sprinkled on the second, third and fourth batches (put in jute bags) three times (morning, afternoon and night) daily to slightly aid germination and probably maintain cool temperature. Both non-germinated and germinated nuts were ground into flour and used for analysis.

\section{Proximate Composition Analysis}

The method described by A.O.A.C. $\{1990\}$ was used to determine the crude protein, crude fiber, and moisture content respectively.

Oil and total ash content was determined as described by Pearson $\{1976\}$. Carbohydrate content of the sample was obtained by the difference method.

\section{Analysis of Antinutritional Constituents of African walnut flour}

The procedure followed in the determination of total oxalate was as described by Holloway et al. $\{1989\}$.

The procedure described by Latta and Eskin $\{1980\}$ but later modified by vaintraub and lapteva $\{1988\}$ was used to determine phytate.

\section{Determination of functional properties}

The method described by Giami $\{1993\}$ was used to determine bulk density. The procedure described by Beuchat $\{1977)$ was used to determine WAC.

\section{Organoleptic Analysis}

Organoleptic test was carried out on non-germinated and germinated walnuts using a randomly selected 30 member panelist. The panelists were asked to rate the samples on color/appearance, texture, aroma, taste, mouthfeel after- taste and general acceptability based on the 9-point hedonic scale ranging from disliked extremely (1) to liked extremely (9).

\section{Statistical Analysis}

The data collected from all analysis were subjected to analysis of variance ratio in order to determine if there is any significant difference. The Tukey test was used to separate the means.

\section{RESULTS AND DISCUSSION}

The proximate composition of African walnut (T. Conophorum) showed the following on percentage wet basis; moisture 19.21 protein (14.93) oil (45.84) fibre (1.17) ash (3.5) and carbohydrate (15.39) while that of geminated sample varies with time of germination (Table 3 ). The result justifies the inclusion of T. conophorurn as an oil rich nut as reported by Adefarati (1985); Okoye (1986), and Okoye et al. (1986) on their works on lesser known and under-utilized tropical oil seeds. The oil of conophor nut has far back and even recently been ascertained suitable for industrial and domestic uses especially in the production of white glass paints and varnishes (Asiagwu et al., 2008).

The result also revealed that the protein content fairly Compares with legumes and is much higher than those Obtained from some Australian varieties (Harold and Tatura, 2002). In comparison, its oil-protein ratio falls within the range reported by Edem et al., (2009). 
TABLE 1: EFFECT OF GERMINATION ON PROXIMATE COMPOSITION (\%) OF AFRICAN WALNUT

\begin{tabular}{lllll}
\hline NUTRIENT & \multicolumn{1}{c}{ RW } & \multicolumn{1}{c}{ GWD1 } & GWD4 & \multicolumn{1}{c}{ GWD8 } \\
\hline MOISTURE & $19.21 \pm 0.01$ & $19.22 \pm 0.01$ & $22.48 \pm 0.02$ & $21.14 \pm 0.01$ \\
CHO & $15.39 \pm 0.02$ & $15.34 \pm 0.02$ & $13.99 \pm 0.01$ & $11.02 \pm 0.01$ \\
PROTEIN & $14.90 \pm 0.02$ & $14.93 \pm 0.02$ & $14.98 \pm 0.01$ & $14.80 \pm 0.01$ \\
FAT & $45.84 \pm 0.01$ & $45.83 \pm 0.02$ & $46.38 \pm 0.02$ & $45.62 \pm 0.02$ \\
FIBRE & $1.17 \pm 0.02$ & $1.17 \pm 0.02$ & $1.16 \pm 0.01$ & $1.14 \pm 0.02$ \\
ASH & $3.50 \pm 0.02$ & $3.50 \pm 0.01$ & $3.52 \pm 0.01$ & $3.52 \pm 0.01$ \\
\hline
\end{tabular}

Values are means of triplicate analysis

RW $=$ RAW WALNUT

$\mathrm{GWD}_{1}=$ GERMINATED WALNUT DAY I

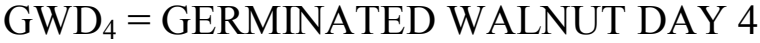

$\mathrm{GWD}_{8}=$ GERMINATED WALNUT DAY 8

The firbe content is similar to those of other oil seeds (Enujiugha and Ayodele-Oni, 2003).

It was observed that germination caused an increase and subsequent depletion of moisture, protein and fat. The increase in moisture content corroborates the work of Kordylas (1990) which reported that during the process of germination, the cells are liberated and the seeds absorb water and swell. Also the water sprinkled on the nuts during sample preparation must have increased the availability of moisture for absorption by cells of the nuts, thus leading to higher moisture content of the germinating nuts.

The reported increase in protein could be attributed to the liberation of bound proteins during germination in line with the work of Uwaegbule et al.; (2012). Similarly, Hsu et al.; (1980) earlier observed that protein content generally increased during germination as a result of biochemical changes induced by sprouting leading to an increase in free amino acids. Related observations on increase in protein content during germination have been recorded in research works (Akpapunan and Achinewhw, 1985; Tiani, 1993; Obatolu et al. (2001). Also Inyang and Zakari (2008) and Yagoub et al. (2008) reported increased protein content during germination of various cereals, legumes and other seeds. This increase according to Nwasike (1995) could be attributed to a net synthesis of enzymic protein (e.g. proteases) by germinating seeds.

Fat content of the germinated walnut (GWD4) was significantly $(\mathrm{P}<0.05)$ higher than that of the ungerminated sample especially on the fourth day of germination. This may be as a result of increased activity of lipolytic enzymes which produce more free fatty acids during sprouting (Uwaegbute et al., 2012).

Contrarily, there was depletion in moisture, protein and fat contents as germination progresses (day 8) as against the observation of Uwaegbute et al. (2012) that protein value increases as the time of germination increased. Germination has been found to result in break down of some stored proteins, carbohydrates and oils into forms of energy for the young sprout to grow roots and shoots (Mubarak, 2005; Hahm et al., 2009; Bahari 2012). Also Onwuka et al. (2009) noted that decrease in fat contents of germinated seeds might be due to the extensive activities of lipolytic enzymes during germination which hydrolyse fats to simpler products which can be used as a source of energy for developing embryo. A corresponding observation was made for bambara groundnut (Elegbede, 1998) and malted millet (Inyang and Zakari, 2008).

Total carbohydrate content decreased significantly at the end of the investigation. This corroborates the work of Yagoub et al. (2008) and Inyang and Zakari (2008). The decreased carbohydrate levels of the germinated seeds might be due to increase in-amylase activity as suggested by Lasekan (1996). -amylase breaks down complex carbohydrates to simpler and more absorbable sugars which are utilized by the growing seedlings during germination.

There was no significant $(p>0.05)$ change in fibre and ash contents of the samples within the period of germination. Generally, the observed increase in some nutrients (protein, fat) was due to biochemical changes that occur during germination which led to their liberation (Obizoba and Egbuna, 1992) while their subsequent depletion was consequential to their being utilized by the young growing shoots. 
The mineral analysis of African walnut flour showed that T. conophorum was rich in magnesium, calcium and potassium (Table 4) but low in concentration of sodium, zinc, iron and copper. This corroborates the work of Sibbeth (1994) and Enujiugha (2003) that walnut is a good source of potassium and many other micronutrients. This implies that for human consumption, African walnut could be recommended as a good source of minerals needed for body metabolism and functionality of cells (Ihemeje et al., 2012)

TABLE 2: MINERAL CONTENT OF RAW AND GERMINATED WALNUT

\begin{tabular}{ccccc}
\hline MINERAL & RW (\%) & GWD1 & GWD4 & GWD8 \\
\hline $\mathrm{Ca}$ & $45.01 \pm 0.02$ & $45.00 \pm 0.02$ & $46.43 \pm 0.01$ & $45.99 \pm 0.02$ \\
$\mathrm{~K}$ & $23.14 \pm 0.01$ & $23.13 \pm 0.01$ & $23.72 \pm 0.02$ & $23.60 \pm 0.02$ \\
$\mathrm{Fe}$ & $2.93 \pm 0.01$ & $2.93 \pm 0.01$ & $2.98 \pm 0.01$ & $2.94 \pm 0.01$ \\
$\mathrm{Mg}$ & $60.20 \pm 0.03$ & $60.24 \pm 0.02$ & $61.00 \pm 0.04$ & $60.59 \pm 0.04$ \\
$\mathrm{Cu}$ & $2.05 \pm 0.04$ & $2.05 \pm 0.04$ & $2.12 \pm 0.04$ & $2.11 \pm 0.02$ \\
$\mathrm{Zn}$ & $5.96 \pm 0.01$ & $5.98 \pm 0.02$ & $6.02 \pm 0.02$ & $6.02 \pm 0.01$ \\
\hline
\end{tabular}

Values are means of triplicate analysis.
RW $=$ RAW WALNUT

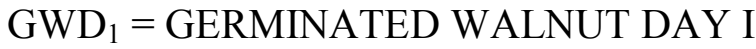
$\mathrm{GWD}_{4}=$ GERMINATED WALNUT DAY 4

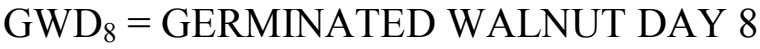

Germinated samples (GWD4) were found to be fairly higher in mineral contents although the mineral elements depleted as the germination time increased (GWD8). The enhancement of mineral availability may be as a result of antinutrient (e.g phytate) decomposition, thus releasing the bound nutrients. The result agrees with the report of Obizoba and Egbuna (1992) who on their investigation on effects of germination and fermentation on the nutritional quality of bambara nut discovered that hydrolysis and other metabolic changes during germination freed the nutrients from their bound forms thus increasing their quality and availability. Azeke et al. (2011) and Sokrab et al. (2012) respectively discovered that the concentrations of phytate and tannins were decreased during germination which led to availability of minerals in seeds and nuts. Phytate (or phytate acid) and tannins (including other anti nutrients) have been implicated in binding of minerals like iron, zinc etc thereby making them metabolically unavailable for assimilation in human body.

TABLE 3: SOME ANTINUTIRTIONAL CONSTITUENTS OF CONOPHOR FLOURS

\begin{tabular}{cccccc}
\hline Sample & RW & CW & GWD1 & GWD4 & GWD8 \\
\hline $\begin{array}{c}\text { Tannins } \\
\text { (mg/100g) }\end{array}$ & $1.3 \pm 0.01$ & $0.11 \pm 0.01$ & $1.3 \pm 0.02$ & $1.21 \pm 0.01$ & $1.12 \pm 0.11$ \\
$\begin{array}{c}\text { Oxalate } \\
(\mathrm{mg} / 100 \mathrm{~g})\end{array}$ & $3.01 \pm 0.1$ & $1.17 \pm 0.02$ & $3.00 \pm 0.02$ & $2.98 \pm 0.02$ & $2.13 \pm 0.02$ \\
$\begin{array}{c}\mathrm{HCN} \\
\text { (mg/100g) }\end{array}$ & $13.01 \pm 1.02$ & $3.33 \pm 0.02$ & $1.300 \pm 0.03$ & $12.09 \pm 0.009$ & $10.02 \pm 0.24$ \\
$\begin{array}{c}\text { Phytate } \\
\text { (mg/100g) }\end{array}$ & $3.00 \pm 0.05$ & $1.10 \pm 0.06$ & $2.98 \pm 0.02$ & $2.42 \pm 0.01$ & $1.89 \pm 0.31$ \\
$\begin{array}{c}\text { Saponini } \\
\text { (mg/100g) }\end{array}$ & $1.28 \pm 0.04$ & $1.1 \pm 0.05$ & $1.29 \pm 0.02$ & $1.28 \pm 0.02$ & $1.19 \pm 0.3$ \\
$\begin{array}{c}\text { Trypsin inhibitor } \\
\text { (mg/100g) }\end{array}$ & $1.19 \pm 0.01$ & $0.04 \pm 0.01$ & $1.20 \pm 0.02$ & $1.18 \pm 0.02$ & $1.00 \pm 0.01$ \\
$\begin{array}{c}\text { Alkaloid (mg/100g) } \\
\text { Polyphenol (mg/100g) }\end{array}$ & $0.09 \pm 0.01$ & $0.03 \pm 0.01$ & $0.09 \pm 0.01$ & $0.11 \pm 0.01$ & $0.11 \pm 0.12$ \\
\hline
\end{tabular}

Values are means of triplicate analysis

$\mathrm{RW}=$ RAW WALNUT

$\mathrm{CW}=$ COOKED WALNUT

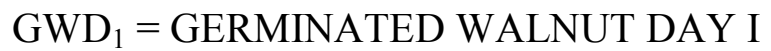

$\mathrm{GWD}_{4}=$ GERMINATED WALNUT DAY 4

$\mathrm{GWD}_{8}=$ GERMINATED WALNUT DAY 8 
The result also proved that alkaloid was decreased by cooking while germination resulted in slight increase in concentration of Saponin and polyphenol on the other hand were less significantly reduced by germination. Germination significantly $(\mathrm{p}<0.05)$ decreased the levels of phytic acid, oxalate and tannins in line with the work of Mubarak (2005); Azeke et al. (2011) and Liang et al. (2008) but generally, cooking brings about improved bioavailability of nutrients more than germination due to the combined effect of heat application and leaching of most antinutrients into the processing water under hydrothermal process.

\section{FUNCTIONAL PROPERTIES OF AFRICAN WALNUT}

The changes in functional properties of walnut samples are shown in table 5.

TABLE 4: FUNCTIONAL PROPERTIES OF RAW COOKED AND GERMINATED AFRICAN WALNUT FLOURS

\begin{tabular}{lllllll}
\hline Sample & \multicolumn{1}{c}{$\begin{array}{c}\text { WAC } \\
(\mathbf{m g} / \mathbf{l}\end{array}$} & \multicolumn{1}{c}{$\begin{array}{c}\text { OAC } \\
(\mathbf{m g} / \mathbf{g})\end{array}$} & \multicolumn{1}{c}{ FC (\%) } & \multicolumn{1}{c}{ EC (\%) } & GC (\%) & BD(\%) \\
\hline $\mathrm{RW}$ & $1.79 \pm 0.03$ & $2.04 \pm 0.02$ & $5.00 \pm 0.11$ & $44.91 \pm 0.21$ & $29.23 \pm 0.11$ & $0.66 \pm 0.03$ \\
$\mathrm{CW}$ & $3.60 \pm 0.22$ & $2.76 \pm 0.12$ & $2.00 \pm 0.01$ & $26.82 \pm 0.22$ & $22.56 \pm 0.21$ & $0.61 \pm 0.12$ \\
$\mathrm{GWD}_{1}$ & $1.80 \pm 0.04$ & $2.04 \pm 0.02$ & $5.00 \pm 0.11$ & $44.02 \pm 0.1$ & $29.05 \pm 0.12$ & $0.66 \pm 0.03$ \\
$\mathrm{GWD}_{4}$ & $2.88 \pm 0.24$ & $2.06 \pm 0.2$ & $4.98 \pm 0.2$ & $38.00 \pm 0.2$ & $28.17 \pm 0.23$ & $0.64 \pm 0.21$ \\
$\mathrm{GWD}_{8}$ & $2.92 \pm 0.10$ & $2.10 \pm 0.30$ & $4.97 \pm 0.21$ & $30.01 \pm 0.03$ & $27.06 \pm 0.02$ & $0.62 \pm 0.11$ \\
\hline
\end{tabular}

Value are means of triplicate determination

WAC: WATER ABSORPTION CAPACITY

OAC: OIL ABSORPTION CAPACITY

PC: $\quad$ FOAMING CAPACITY

EC: EMULSION CAPACITY

GC: GELLING CAPACITY

BD: BULK DENSITY

\section{Water Absorption Capacity (WAC)}

Cooking and germination improved the WAC of the walnut samples above that of the raw sample. Cooking led to the highest WAC value $(3.60 \mathrm{ml} / \mathrm{g})$ followed by germination $(2.92 \mathrm{ml} / \mathrm{g})$. The significant increase in WAC could be attributed to the effect of heat application (in terms of cooking) while starch cells become more hydroscopic during germination (Kordylas, 1990).

Similar results of increase in WAC by heat processing have been reported on sunflower proteins (Lin et al., 1974), winged been flour (Narayana and Narasinga-Rao, 1982), cowpea flour (Abbey and Ibeh, 1988) and African yam been flour (Eke and Akobundu, 1993). Narayana and Narasinga Rao (1982) suggested that protein submit structures which dissociate on heating may have more water binding sites than the oligometric protein. Gelatinization of carbohydrate and crude fibre on heating also contributed to the increased water absorption.

Giami (2003) indicated that water absorption capacity is an indication of the extent to which proteins can be incorporated into aqueous food formulations. In similar view, Ige et al., (1984) earlier justified that the inclusion of conophor flour in composite flour production was due to its water absorption capacity.

\section{Emulsion Capacity (EC)}

Emulsion capacity of conophor nut was significantly $(\mathrm{P}<0.05)$ reduced by cooking and germination. The trend (Table 4$)$ showed a decreased from the raw $(44.91 \%)$ to cooked $(26.82 \%)$. Reduction in emulsion capacity of the samples may be probably influenced by their respective oil contents. Germination led to depletion of oil content as time increases. Another possible cause of the reduction could be the thermal denaturation of protein caused by heating (Rawson et al., 2011). 


\section{Foam Capacity (FC)}

Germination led to slight decrease in foam capacity of the sample while cooking remarkably its reduced foaming capacity (Table 4) The reduced foaming capacity was possibly caused by heating. Similar effect of heat processing on foam capacity and stability of cowpea flour (Giami, 2003) and winged bean flour (Okpala and Manach, 2000) has been reported. Lin et al. (1974) earlier stated that foamability (of flours) is related to the amount of native protein in the sample. This implies that reduced foaming capacity of samples can be explained on the basis of heat application and protein denaturation.

\section{Gelling Capacity}

Gelation concentration of raw, germinated and cooked conophor samples were recorded in Table (4) Cooking resulted in reduced gelling capacity of the sample which may be as a result of denaturation, aggregation and thermal degradation of starch (Enwere and Ngoddy, 1986). Enujiugha et al. (2003) further suggested that gel forming ability is known to be influenced by the nature of protein, starch and gums in the sample as well as their interaction during heat treatment. Thus raw or mildly heat processed samples have greater gelling capacity than high temperature processed food materials. This explains why raw and germinated samples formed better gels than the boiled (cooked) sample.

\section{Oil Absorption Capacity}

Table (4) presents the oil absorption capacity of raw, cooked and germinated conophor samples. Boiling and germination respectively caused an increase in oil absorption capacity of the sample above that of the raw $(2.04 \mathrm{ml} / \mathrm{g})$.

The increased oil absorption capacity of heat processed sample may be due to the denaturation and dissociation of their constituent proteins that occur on heating which unmasks the non-polar residues from the interior of the protein molecule (Odoemelam, 2005) while the increase in oil absorption capacity of germinated sample may be attributed to the increased activity of lipolytic enzymes which produce more free fatty acids during sprouting. These results corroborate the work of Delrossano and Flora (1981) and Eneche (2003) who respectively noted that germination increased the oil absorption capacity of African yam bean flour. Oil absorption capacity is an indication of the rate at which proteins bind to fat in food formulations. Absorption of fat or oil by food products improves their mouth-feel and flavour retention.

\section{Bulk Density}

The functional properties of raw, boiled and germinated walnut samples are shown in Table (4) Boiling and germination caused reduction in the bulk density of the raw sample. The result corresponds with the work of Eke and Akobundu (1993) on the effects of heat application on bulk density of African yam bean (Sphenostylis sterrocarpa) seed flour implying that heat treatment decreases bulk density. Also Enujiugha (2003) observed reduction in bulk density due to heat application.

\section{SENSORY EVALUATION}

The sensory evaluation of walnut samples are shown in Table (5) Results indicate that samples GW and FCW, had no significant difference in terms of taste, aroma and mouth-feel. There was significant difference between FCW and GC especially in colour, after-taste and general acceptability. The higher concentration of alkaloids and polyphenol in GC could be responsible for its strong after taste. This made the sample very objectionable to consumers. Sample FCW was most preferred in terms of general acceptability.

$\mathrm{GC}=$ Germinated \& cooked.

$\mathrm{RCW}=$ Freshly cooked walnut. 
TABLE 5: SUMMARY OF SENSORY EVALUATION OF AFRICAN WALNUT SAMPLES

\begin{tabular}{llll}
\hline Parameter & FCW & GC & SD \\
\hline Taste & $8.2^{\mathrm{a}}$ & $4.93^{\mathrm{b}}$ & 1.97 \\
After Taste & $26.1^{\mathrm{c}}$ & $18.3^{\mathrm{b}}$ & 4.076 \\
Mouth feel & $25.5^{\mathrm{a}}$ & $21.9^{\mathrm{b}}$ & 2.9119 \\
Aroma & $25.5^{\mathrm{a}}$ & $16.8^{\mathrm{b}}$ & 3.77 \\
Colour & $8.2^{\mathrm{a}}$ & $4.0^{\mathrm{b}}$ & 2.137 \\
General & $19.8^{\mathrm{a}}$ & $9.6^{\mathrm{b}}$ & 8.10 \\
acceptability & & & \\
\hline
\end{tabular}

GC: $\quad$ Germinated \& Cooked

FCW: Freshly cooked walnut (non-germinated)

\section{CONCLUSION AND RECOMMENDATION}

The result of this study revealed that germination led to enhancement (or availability) of nutrient composition of walnut followed by subsequent depletion as the germination continued for a long time because the growing shoot uses the available nutrients as sources of energy for growth. The protein and mineral binding substances (antinutrients) were decomposed as germination progressed. This significantly contributed to increase in nutritional composition of the samples especially the minerals.

Water absorption capacity (WAC) of the flour was improved by germination thus increasing its the industrial potentials or applications in composite flour production. Evaluation of sensory attributes showed that freshly boiled walnut was very much preferred to "germinated and boiled" walnut in terms of taste after taste and general acceptability. Cooking brought about greater antinutrient destruction and sensory attributes than germination.

\section{RECOMMENDATION}

I recommend that germination of walnut may be adopted by industries that use walnut in the production of composite flour for baking since germination has been found to improve the functional property of the flour. On the other hand, sellers and consumers of African walnut should avoid germinated (especially) nuts for their objectionable sensory attributes.

\section{REFERENCES}

[1] Adefarati, F.B. (1985). Development of non-edible oils for use in the Nigerian Surface Coating industry with particular reference to rubber seed oil (Hevea Brasiliences) for Manufacture of air drying oil alkyds. Paper presented at the National Conference on the Industrial Utilization of Natural Rubber seed, Latex and Wood; held at Rubber Research Institute of Nigeria (RRIN) Iyanomo, Benin City, Bendel State, Nigeria. 22-24 January 1985, p. 24

[2] Ajaiyeoba, E.O. and Fadare, D.A. (2006). Antimicrobial potential of extracts and fractions of the African walnut (Tetracarpidium conophorum) African Journal of Biotechnology . 5 (22): 2322-2326.

[3] Altschul, S.V.R. (1975). Drugs and Foods from little known plants, Harvard University Press, London p. 170.

[4] Akpapunam, M.A. \& Achinewhu, S.C. (1985). Effect of cooking, germination and fermentation on the chemical composition of Nigeria cowpea (Vigna unguiculata). Plant Food Hum. Nutr. 35,353-358.

[5] A.O.A.C. (1990). Official Method of Analysis. $15^{\text {th }}$ ed. Association of Official Analytical Chemists, Virginia, U.S.A.

[6] A.O.A.C. (1999). Official Method of Analysis. $16^{\text {th }}$ ed. Association of Official Analysis Chemists Washington D.C. pp. 930-935. 
[7] Beuchat, L.R. (1977). Functional and Electrophoretic properties of sucinylated peanut flour proteins. J. Agri. and Food Chem. 25: 258-260.

[8] Bingham, S. (1977). Nutrition: A Consumer's Guide to Good Eating, Transworld Publishers, London. p.450

[9] Change, S.E. and Fuller, H.L. (1964). Effect of Tannic acid Content of grain Sorghum on their feeding value for growing Chick. Poultry Sci. 43: 30-60.

[10] Coffmann, C.N. and Garcia, V.A. (1977). Functional properties of the protein isolate from Mung bean flour. J. Food Tech. 12: 473-478.

[11] DelRosano, R.R. \& Flore, D.M. (1981). Functional properties of flour types of mung bean flours. J. Sci. Fd. Agric. 32:175-180.

[12] Edem, D.O., Ekwere, E.S. and Eke, O.U. (1994). Chemical Evaluation of the Effect of Cooking on the Nutritive value of Cooking on the Nutritive value of Conophor seed (Tetracarpidium Conophorum), Tropical Sci. 34: 377-380.

[13] Eneche, E.H. (2003). Preparation and Physiological properties of flours and protein concentrates from raw and germinated AYB (Sphenostylis stenocarpa). Proceedings of Annual Conference and Scientific meeting of Nutrition Society of Nigeria. 158-1616.

[14] Encyclopedia Americana (1994). Grolier Incorporated International Edition, Vol. 20. P.575.

[15] Enujiugha, V.N. (2003). Chemical and Functional Characteristics of Conophur Nut. Pakistan J. of Nutrition. 2 (6) :335-338.

[16] Enujiugha, V.N. and Ayodele-Omi, O. (2003). Evaluation of nutrients and some antinutrients in lesser known under-utilized oil seeds. Int. J. Food Sci. and Tec. 38: 525-528.

[17] Forbes, R.M. and Erdman, J.W. (1983). Bioavailability of tree mineral elements. Annual Review of Nutrition 3:213-231

[18] Ford, J.E. and Hewitt, D. (1979). Protein Quality of Cereal and Pulses. I. Application of Microbiological and other in-vitro methods in the evaluation of rice (Oryza sctiva), Sorghum (Sorghun vulgare), barley and field bean (Vivia Faba). British J. of Nutri. 33: 314-352.

[19] Giami, S.Y. (2003). Effect of processing on the proximate Composition and Functional Properties of Cowpea (Vigna Ungniculate) flour. Food Chem. 47:153-158.

[20] Harland, B.F., Oke, O.L. Felix-Phipps, R. (1988). Preliminary studies on the phytate content of Nigerian foods. Journal of Food Composition and Analysis. 1:202-205.

[21] Hemery, G.E. (2001). Growing Walnut in Mixed Stands. Quarter J. Forestry. 95:31-36.

[22] Hitchcock, C.L. and Arthur, C. (1979). Flora of the Pacific North West, University of Washington Press, Seatle and London. p. 284.

[23] Hutchinson, J. and Dalziel, J.M. (1958). Flora of West Tropical African. Vol. 1, part 2. Crown Agents for Oversea Governments and Administrations, Millbank, London S.w. I.p. 410.

[24] Hsu, D.L. Leury, H.K. Finney, P.L. \& Morad, M.M. (1980). Effects of germination of the nutritive value and baking properties of dry peas, lentils and faba beans. J. Fd. Sci. 45:87-90.

[25] Ihemeje, A., Okorie, S.U. and Ekwe, C.C. (2012) Effects of processing methods on the biochemical, functional and antinutritional properties of Afrcian Walnut (Tetracarpidium conophorum). Journal of Biology Science and Bioconservation p.4:55-64

[26] Inyang, C.U. \& Zakari, U.M. (2008). Effect of Germination and Fermentation of Pearl Millet on Proximate, Chemical and Sensory Properties of Instant "Fura". A Nigerian Cereal Food. Pak. J. Nutr. 7(1):9-12.

[27] Kinsela, T. and Bezard, J. (1993). Evaluation of lesser known oil seeds. International J. of Food Sci. and Techno. 13 (3) 567-575.

[28] Lonnerdahl, B., Sandberg, A., Sandstrom, B. and Kunz, C. (1989). Inhibitory effects of phytic acid and other Inositolphosphates on zinc and calcium absorption in sucking rats. J. Nutri. 119:211-214.

[29] Margen, S. (2006). Preservation of African Walnut. Encyclopedia of Food and Nutrition Rebus New York. Pp. 1-2. 
[30] Mohammed, R.K. Abuo-Arab, E.A. Gibriel, A.Y., Nagwa M.H. Rasmy, H.M. \& Abu-Salem, F.M. (20110. Effect of legume processing treatments individually or in combination on their phytic acid content. African journal of Food Science and Technology 2(2):036-046.

[31] Mubarak, A.E. (2005). Nutritional composition and antinutritional factors of mung bean seeds (phaseolus aureus) as affected by some home traditional processes. Food Chem. 89:489-495

[32] Narayana, N. and Narasinga-Rao, N. (1982). Foundational properties of Raw and Heat Processed wing bean (pseohorcarpus tetragonobbies). J. Food Sci. 47:1534-1538.

[33] Norris, P.E. (1974). About Nut Dried Fruit. Thompson's Publishers Ltd. Wellingbrough. p. 63.

[34] Obizoba, I.C. and Egbuna, H.I. (1992). Effect of germination and fermentation on the nutritional quality of bambara nut (voandeiz subterrance L. Thouars) and its product (milk). Plant foods for Human Nutrition 42(1):13-23

[35] Obizoba, I.C., \& Nnam, M.N. (1992). The effects of sprouting time on nutritive value of two varities of Africnan yam bean (Sphenostlis stenocarpa). Plant ds. Hum. Nutr. 42:319-327

[36] Onwuka, C.F. Ikewuchi, C.C. \&, Ikewuchi C.J. \& Ayalogu, O.E. (2009). Effect of Germination on the performance characteristics of African Yam Bean (Sphenostylis stenocarpa Hochst ex A Rich) Seed Meal on Albino Rats. J. Appl. Sci. Environ. Mange. 13(2) 51-53.

[37] Oke, O.L. (1967). Chemical Studies on the more Commonly used leaf vegetables in Nigeria. Journal of the West African Science Association. 11 (1 and 2) :42-48.

[38] Okoye, W.I. and Okobi, A.O (1984). Physical and Chemical parameters of some less known Nigeria oil seeds. Nigeria Stored Product Research Institute, Ilorin. Technical Report No. 12. pp. 101-109.

[39] Okoye, W.I., Okobi, A.O. and Okonkwo, U.E. (1986). Extraction and characterization of oils from nine lesser known Nigeria oil seeds. Nigeria Stored Products Research Institute Ilorin. pp. 8-10.

[40] Oladokun, M.A.O. (1990). Tree crop based agroforestry in Nigeria; a checklist of crops intercropped with Cocoa. Agroforestry Systems. 11:227-241.

[41] Ologhobo, A.D. and Fetusa, B.L. (1983). Investigations on the trypsin; hibition, haemagglutinin, phytic and tannic acid contents of cowpea (Vigna unquiculata). Food Chemistry 12:249-254.

[42] Ologhobo, A.D and Fetuga, B.L. (184). Distribution of phosphorus and phytate in some Nigeria varieties of legumes and some effects of processing. Journal of Food Science. 49: 199-201.

[43] Osagie, A.U. and Okoye, W.I (1986). Chemical quality parameters of fatty acid cornposition of oils of some under-exploited tropical seeds. paper presented at the National Workshop on Nutrient composition of Foods at University of Ibadan. March $31^{\text {st }}-5^{\text {th }}$ April.

[44] Osagie, A.U. Muzqniz, M., Burbano, C., Cuadrado, C., Ayet, G. and Castano, A. (1996). Anti nutritional constituents of ten staple foods grown in Nigeria. Tropical Science. 36:109-115.

[45] Oyenuga, V.A. (1975). The Nutritional value of conophor seed (Tetracarpidium conophorum). IN proceedings of the Conference on Animal feeds of Tropical and sub-tropical origin. London. pp. 161-166.

[46] Osuntokun, B., Monekosso, G.L. and Wilson, J. (1969). Cassava diet and chronic degenerative neuropath: an epidemiological study. Nigeria J. Sci. 3:3-15.

[47] Pearson, D. (1976). The Chemical Analysis of food $2^{\text {nd }}$ edition. Longman Group Ltd., Edinburgh, London and New York.

[48] Pyenson, L. (1970). Plant Health Hand book., AV1 Publishing Company Inc. West Port, Connecticut. p. 197.

[49] Riley, H.P. (1963). Families of flowering plants of Southern African. University ofKentucky Press, Lexcington Kentucky. p. 76.

[50] Ros, E. (2006). Health Benefits of Walnuts. Journal of the American College of Cardiology 2006 edition. p. 3. 
[51] Shukla, P. and Shitalp, C. (1979). An Introduction to Angisperms. Macmillan Publishers. New York. pp. 317-325.

[52] Sibbett, S.G. (1994). Edible Tree Nuts, Walnuts. Encyclopedia of Agricultural Science 2:916.

[53] Thompson, B. (1976). Black Walnut for profit. Timber Press, Forest Grove, p. 193.

[54] Thonner, F. (1962). The Flowering Plants of Africa. Wheldon and Wesley Ltd., Codicote. p. 309.

[55] Una, V.D. (1973). Gardening with shrubs. Hugh keartland Ltd. Johannes burg. p. 160.

[56] Uwaegbute, A.C. Ukegbu, P.O. and Ikpeoha, A. (2012). Effect of germination on cooking, Nutrients composition and organoleptic qualities of African Yam Bean (Spherstyllis stenocarpa). J. Biol., Agric Healthcare 2(8):28-32.

[57] Willis, J.C. (1973). A Dictionary of the Flowering Plants and Ferns, Seventh ed., Cambridge University Press Cambridge, p. 1108.

[58] Yatsumatsu, K., Sawada, K. and Moritake, S. (1972). Whipping and emulsifying properties of Soyabean products Agri. Biol. Chem. 36 (5) 719-727. 